MINI-REVIEW

\title{
Resistin - a mediator of obesity-associated insulin resistance or an innocent bystander?
}

\author{
Olavi Ukkola \\ Department of Internal Medicine and Biocenter Oulu, University of Oulu, Kajaanintie 50/PO Box 5000, FIN-90220 Oulu, Finland \\ (Correspondence should be addressed to Olavi Ukkola; Email: olavi.ukkola@oulu.fi)
}

\begin{abstract}
The objective of this review is to summarize the current evidence of a novel adipocytokine, resistin. Resistin is a novel peptide hormone that belongs to a family of tissue-specific resistin-like molecules originally named for its resistance to insulin. Although a seminal proposal by Steppan et al. suggested resistin to be a hormone that links obesity to diabetes, several studies have subsequently been published supporting the concept that insulin resistance and obesity are actually associated with a decreased resistin expression. Resistin expression is regulated by a variety of agents and hormones, including thiazolidinediones, insulin, tumor necrosis factor alpha and growth hormone. Studies about their role in the regulation of resistin expression are, however, inconsistent in many cases. Experiments in humans have shown no differences in resistin expression between normal, insulinresistant or type 2 diabetic samples. However, some recent genetic studies have demonstrated an association between resistin and insulin resistance and obesity. In addition, regional variation in the expression of resistin mRNA and protein levels in humans is an interesting finding with the highest levels found in the abdominal depot. In conclusion, resistin is a fascinating new hormone for which a definite role in metabolism will be revealed in the near future.
\end{abstract}

European Journal of Endocrinology 147 571-574

\section{Introduction}

It has become clear that adipose tissue and free fatty acids are key regulators of insulin sensitivity. Ectopic fat storage has recently been hypothesized to be one of the links between adiposity and insulin resistance (1). Another aspect is the endocrinological role of adipose tissue - it is known to secrete a large number of proteins (2). Among them, resistin is a novel signalling molecule induced during adipogenesis (3). It was originally named for its resistance to insulin. Resistin circulates in the blood (3) and it is a peptide hormone that belongs to a family of tissue-specific resistin-like molecules (4). The resistin mRNA encodes a 114 amino acid polypeptide containing a 20 amino acid signal sequence (5). Resistin is expressed in white adipose tissue with the highest levels in female gonadal adipose tissue (5). The adipocyte specificity of resistin gene expression is though to be caused by CCAAT/ enhancer-binding protein alpha $(\mathrm{C} / \mathrm{EBP} \alpha)$ binding (6). C/EBPs are a family of transcription factors that, like the peroxisome proliferator-activated receptor (PPAR) system, have been shown to be important in the regulation of adipocyte differentiation (7).

In this review the current evidence for and against the role of resistin in metabolic abnormalities is briefly summarized. This overview emphasizes the fact that the fundamental role of resistin in animals and, particularly, in humans is still unclear even though the knowledge is expected to grow all the time.

\section{The role of resistin in insulin resistance and obesity}

\section{Evidence for}

The seminal proposal by Steppan et al. suggested resistin to be a hormone that links obesity to diabetes (3). Resistin serum levels were increased in obesity and resistin gene expression was induced during adipocyte differentiation (Fig. 1). In addition, administration of resistin impaired glucose tolerance and insulin action while neutralization of resistin reduced hyperglycemia in the mouse model of diet-induced insulin resistance (3). Anti-resistin IgG also potentiated insulin-stimulated glucose uptake supporting the notion that resistin's effects on glucose metabolism were antagonistic to those of insulin. In line with these findings Kim et al. (8) reported that resistin's mRNA levels were markedly increased during 3T3-L1 and primary preadipocyte differentiation into adipocytes. They also showed that resistin mRNA levels were low during fasting but increased markedly when fasted mice were refed or after insulin administration. However, resistin 
had an inhibitory effect on adipose conversion and was, therefore, speculated to be a feedback regulator of adipogenesis and a signal to restrict adipose tissue formation (8). Recently, another gene expression study demonstrated that adipose tissue increases expression of multiple genes, including resistin, at the onset of high-fat-diet-induced obesity in rats (9). Peroxisome proliferator-activated receptor gamma (PPAR $\gamma$ ) induces adipocyte differentiation (10). Thiazolidinediones, such as rosiglitazone, are ligands for the nuclear receptor PPAR $\gamma$ and produce insulin sensitizing effects (11). Interestingly, rosiglitazone treatment has been shown to decrease resistin mRNA $(6,12,13)$ and serum levels (3). Li et al. created a transcription factor that activated transcription of PPAR $\gamma$-responsive genes in the absence of ligand by fusion of the potent viral transcriptional activator VP16 to PPAR 22 (VP16PPAR $\gamma$ ) (14). Resistin gene expression was reduced in VP16-PPAR $\gamma$ adipocytes treated with thiazolidinediones.

Regional variation in the expression of resistin has also been observed. Excessive adiposity, particularly abdominal adiposity, is undoubtedly one of the determining factors leading to the clustering of metabolic disturbances observed in the metabolic syndrome. A recent report suggests an increase in resistin mRNA expression in abdominal depots compared with thigh (15) providing one explanation for the increase in metabolic abnormalities in abdominal obesity. The same group has recently confirmed the increased expression of resistin in abdominal fat also at the protein level (16).

\section{Evidence against}

Way et al. were the first to demonstrate that experimental obesity in rodents is associated with severely defective resistin expression (17). Subsequently, several studies have been published supporting the concept that insulin resistance and obesity are actually associated with decreased resistin expression. For instance, an insulin-resistant rat model experienced suppressed gene expression of adipocyte resistin gene (18). Free fatty acids were found to suppress the expression of resistin gene in normal rat adipocytes. Beta-adrenergic stimulation, which activates lipolysis and free acid release inducing insulin resistance, has been found to decrease resistin gene expression in 3T3-L1 adipocytes (19). Insulin has been suggested as a major inhibitor of resistin production (13), which may explain the low resistin mRNA levels in insulin resistance. Also tumor necrosis factor alpha, elevated in obesity, inhibits resistin gene expression (20). In addition, the transgenic mice developing high-fat diet-induced obesity exhibited downregulated adipocyte resistin mRNA levels in isolated fat cells (21). Beta 3-adrenergic agonists, shown to have antidiabetic and antiobesity properties, have been reported to produce an increase in resistin gene expression in diet-induced obesity in animals (22).
Resistin gene expression did not seem to be involved in the etiology of insulin resistance in Fischer 344 rats that represent a good model for typical metabolic syndrome in humans (23).

Human studies do not provide evidence that resistin is a key player in the development of insulin resistance. Resistin expression in human fat and muscle cells in relation to insulin resistance was studied by Nagaev \& Smith (24). The results suggested that resistin was not detectable at all in human muscle and fat cells. Furthermore, no differences were found between normal, insulin-resistant or type 2 diabetic samples. Similar results were found by Savage et al. (25). They did not detect resistin mRNA in adipocytes from a severely insulin-resistant subject. Although resistin mRNA levels were increased in morbidly obese humans in whole adipose tissue samples, they were very low in freshly isolated human adipocytes. Importantly, PPAR $\gamma$ agonists did not have an effect on mononuclear cell resistin expression (25), being in contrast to several studies in animals $(3,6,12,13)$. It should be pointed out, however, that Way et al. observed that PPAR $\gamma$ agonists actually stimulated adipose tissue resistin expression (17). In addition, Savage et al. (25) did not observe any correlation between body mass index and adipocyte resistin expression. Recently, the expression of the resistin gene in primary cultured human adipocytes and preadipocytes was studied by Janke et al. (26). They found higher expression of the resistin gene in human pre-adipocytes and the expression decreased during adipogenic differentiation to mature cells. In this study resistin gene expression was not related to insulin resistance.

\section{Regulators of resistin expression}

Figure 2 shows the factors that have been reported to regulate resistin gene expression. A number of hormones and agents affect resistin expression but the results are contradictory in some cases, that is the case in insulin's effects on resistin expression. Thiazolidinediones decrease resistin expression in most studies. A recent study suggests that resistin expression is regulated by a variety of hormones (27). Interestingly, growth hormone seems to induce resistin gene expression in white adipose tissue in rats (28).

\section{Genetics of resistin}

The human resistin gene is located on chromosome 19 p13.3 (3). Resistin is encoded by three exons. Systematic search for single nucleotide polymorphisms (SNP) in the resistin gene has yielded genetic variations in the non-coding but not coding region. Recently, three SNPs in the promoter, intron 2 and intron 3 regions were shown to be determinants of insulin sensitivity index in interaction with body mass index 


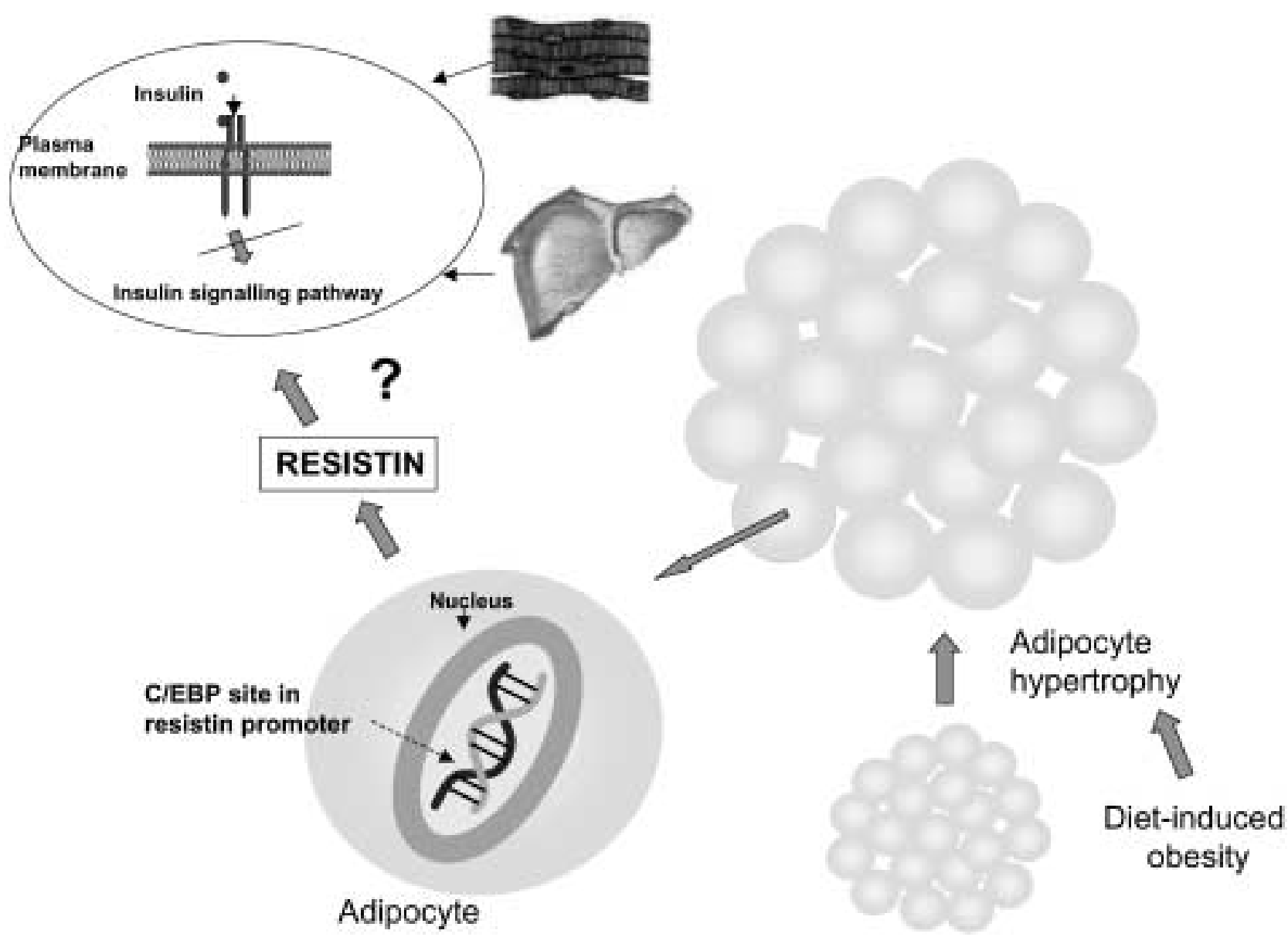

Figure 1 Obesity induced by high fat diet leads to adipocyte hypertrophy and adipocytes secrete a number of factors. Among them, resistin is a novel peptide hormone which is expressed from white adipose tissue (3). The adipocyte specificity of resistin gene expression is caused by binding to CCAAT/enhancer-binding protein (C/EBP) alpha (6) that belong to a family of ligand-activated nuclear transcription factors (7). Resistin circulates in the blood and was suggested to impair insulin action in the original proposal by Steppan et al. (3). However, this view has been challenged by others (17).

\section{Regulators of resistin expression}
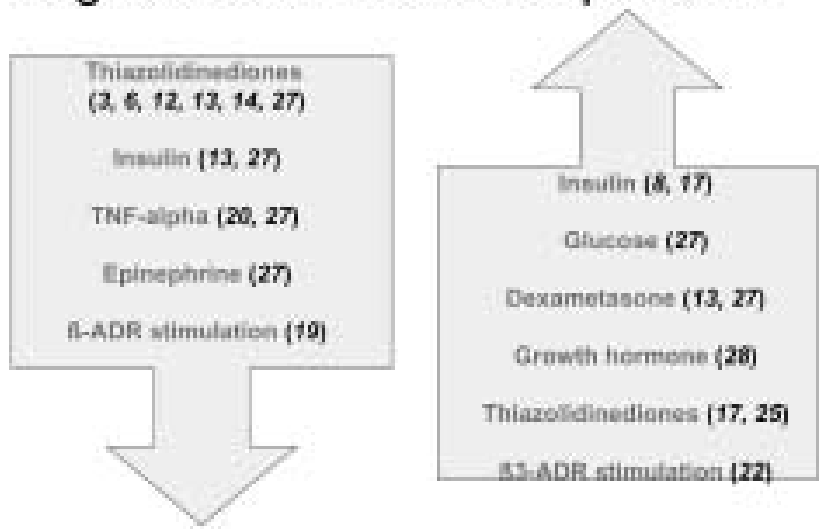

Figure 2 The factors that have been reported to decrease (left) or increase (right) resistin gene expression. ADR, adrenergic receptor. References are shown in parentheses. in a study conducted on individuals of Northern European ancestry in Utah (29). In another study two resistin promoter polymorphisms were associated with obesity among the French Canadian population (30). However, genetic variations at the resistin gene did not show any association with obesity or type 2 diabetes in Italian (31) or Japanese (32) populations.

\section{Conclusions}

Although the first report proposed resistin serum levels to be increased in the obese state, a number of later publications have demonstrated decreased resistin gene expression in obesity. The way resistin was measured and the differences between serum concentrations and mRNA and protein levels probably contribute to the inconsistency observed in these studies. However, this does not necessarily rule out 
the possibility that resistin could still play a role in metabolic disorders. Some recent genetic studies have demonstrated an association between resistin and insulin resistance and obesity. In addition, regional variation in the expression of resistin mRNA and protein levels in humans is an interesting finding with the highest levels found in the abdominal depot. In conclusion, the role of resistin in human diseases and physiology remains elusive. However, the current evidence suggests it to be more an innocent bystander than a real player in metabolic disorders in humans. Now, the challenging task is to investigate the course of resistin expression during the development of insulin resistance. In addition, the genetic knockout of resistin is likely to reveal many of the phenotypic effects of resistin.

\section{References}

1 Ravussin E \& Smith SR. Increased fat intake, impaired fat oxidation, and failure of fat cell proliferation result in ectopic fat storage, insulin resistance, and type 2 diabetes mellitus. Annals of the New York Academy of Science 2002967 363-378.

2 Ahima RS \& Flier JS. Adipose tissue as an endocrine organ. Trends in Endocrinology and Metabolism $200011327-332$.

3 Steppan CM, Bailey ST, Bhat S, Brown EJ, Banerjee RR, Wright $\mathrm{CM}$ et al. The hormone resistin links obesity to diabetes. Nature 2001409 307-312.

4 Steppan CM, Brown EJ, Wright CM, Bhat S, Banerjee RR, Dai CY et al. A family of tissue-specific resistin-like molecules. PNAS 2001 $98502-506$.

5 Steppan CM \& Lazar MA. Resistin and obesity-associated insulin resistance. Trends in Endocrinology and Metabolism 200213 18-23.

6 Hartman HB, Hu X, Tyler KX, Dalal CK \& Lazar MA. Mechanisms regulating adipocyte expression of resistin. Journal of Biological Chemistry 2002277 19754-19761.

7 Darlington GJ, Ross SE \& MacDougald OA. The role of C/EBP genes in adipocyte differentiation. Journal of Biological Chemistry $199827330057-30060$.

$8 \mathrm{Kim}$ KH, Lee K, Moon YS \& Sul HS. A cysteine-rich adipose tissuespecific secretory factor inhibits adipocyte differentiation. Journal of Biological Chemistry 2001276 11252-11256.

9 Li J, Yu X, Pan W \& Unger RH. Gene expression profile of rat adipose tissue at the onset of high-fat-diet obesity. American Journal of Physiology, Endocrinology and Metabolism 2002282 E1334-E1341.

10 Desvergne B \& Wahli W. Peroxisome proliferator-activated receptors: Nuclear control of metabolism. Endocrine Reviews 199920 649-688.

11 Nolan JJ, Ludvik B, Beerdsen P, Joyce M \& Olefsky J. Improvement in glucose tolerance and insulin resistance in obese subjects treated with troglitazone. New England Journal of Medicine 1994 331 1188-1193.

12 Moore GB, Chapman H, Holder JC, Lister CA, Piercy V, Smith SA et al. Differential regulation of adipocytokine mRNAs by rosiglitazone in $\mathrm{db} / \mathrm{db}$ mice. Biochemical and Biophysical Research Communications 2001286 735-741.

13 Haugen F, Jorgensen A, Drevon CA \& Trayhurn P. Inhibition by insulin of resistin gene expression in 3T3-L1 adipocytes. FEBS Letters $2001 \mathbf{5 0 7} 105-108$.

14 Li Y \& Lazar MA. Differential Gene Regulation by PPARgamma Agonist and Constitutively Active PPARgamma2. Molecular Endocrinology $2002161040-1048$.

15 McTernan CL, McTernan PG, Harte AL, Levick PL, Barnett AH \& Kumar S. Resistin, central obesity, and type 2 diabetes. Lancet $200235946-47$.
16 McTernan PG, McTernan CL, Chetty R, Jenner K, Fisher FM, Lauer MN et al. Increased resistin gene and protein expression in human abdominal adipose tissue. Journal of Clinical Endocrinology and Metabolism $2002 \mathbf{8 7} 2407$.

17 Way JM, Gorgun CZ, Tong Q, Uysal KT, Brown KK, Harrington WW et al. Adipose tissue resistin expression is severely suppressed in obesity and stimulated by peroxisome proliferator-activated receptor gamma agonists. Journal of Biological Chemistry 2001 $\mathbf{2 7 6} 25651-25653$.

18 Juan CC, Au LC, Fang VS, Kang SF, Ko YH, Kuo SF et al. Suppressed gene expression of adipocyte resistin in an insulin-resistant rat model probably by elevated free fatty acids. Biochemical and Biophysical Research Communications 2001289 1328-1333.

19 Fasshauer M, Klein J, Neumann S, Eszlinger M \& Paschke R. Isoproterenol inhibits resistin gene expression through a $\mathrm{G}(\mathrm{S})$-protein-coupled pathway in 3T3-L1 adipocytes. FEBS Letters 2001 $\mathbf{5 0 0} 60-63$.

20 Fasshauer M, Klein J, Neumann S, Eszlinger M \& Paschke R. Tumor necrosis factor alpha is a negative regulator of resistin gene expression and secretion in 3T3-L1 adipocytes. Biochemical and Biophysical Research Communications 2001288 1027-1031.

21 Le Lay S, Boucher J, Rey A, Castan-Laurell I, Krief S, Ferre P et al. Decreased resistin expression in mice with different sensitivities to a high-fat diet. Biochemical and Biophysical Research Communications $2001289564-567$.

22 Martinez JA, Margareto J, Marti A, Milagro FI, Larrarte E \& Moreno Aliaga MJ. Resistin overexpression is induced by a beta3 adrenergic agonist in diet-related overweightness. Journal of Physiology and Biochemistry 200157 287-288.

23 Levy JR, Davenport B, Clore JN \& Stevens W. Lipid metabolism and resistin gene expression in insulin-resistant Fischer 344 rats. American Journal of Physiology, Endocrinology and Metabolism 2002282 E626-E633.

24 Nagaev I \& Smith U. Insulin resistance and type 2 diabetes are not related to resistin expression in human fat cells or skeletal muscle. Biochemical and Biophysical Research Communications 2001285 $561-564$.

25 Savage DB, Sewter CP, Klenk ES, Segal DG, Vidal-Puig A, Considine RV et al. Resistin/Fizz3 expression in relation to obesity and peroxisome proliferator-activated receptor-gamma action in humans. Diabetes $2001502199-2202$.

26 Janke J, Engeli S, Gorzelniak K, Luft FC \& Sharma AM. Resistin gene expression in human adipocytes is not related to insulin resistance. Obesity Research $2002101-5$.

27 Shojima N, Sakoda H, Ogihara T, Fujishiro M, Katagiri H, Anai M et al. Humoral regulation of resistin expression in 3T3-L1 and mouse adipose cells. Diabetes 200251 1737-1744.

28 Delhanty PJ, Mesotten D, McDougall F \& Baxter RC. Growth hormone rapidly induces resistin gene expression in white adipose tissue of spontaneous dwarf (SDR) rats. Endocrinology 2002 $1432445-2448$.

29 Wang H, Chu WS, Hemphill C \& Elbein SC. Human resistin gene: molecular scanning and evaluation of association with insulin sensitivity and type 2 diabetes in Caucasians. Journal of Clinical Endocrinology and Metabolism 200287 2520-2524.

30 Engert JC, Vohl MC, Williams SM, Lepage P, Loredo-Osti JC, Faith J et al. $5^{\prime}$ flanking variants of resistin are associated with obesity. Diabetes $2002 \mathbf{5 1} 1629-1634$.

31 Sentinelli F, Romeo S, Arca M, Filippi E, Leonetti F, Banchieri M et al. Human resistin gene, obesity, and type 2 diabetes: mutation analysis and population study. Diabetes $2002 \mathbf{5 1} 860-862$.

32 Osawa H, Onuma H, Murakami A, Ochi M, Nishimiya T, Kato K et al. Systematic search for single nucleotide polymorphisms in the resistin gene: the absence of evidence for the association of three identified single nucleotide polymorphisms with Japanese type 2 diabetes. Diabetes $200251863-866$.

Received 9 July 2002

Accepted 15 July 2002 